\title{
THE EFFECTS OF DRYING METHODS ON TOTAL PHENOLIC AND FLAVONOID SUBSTANCES AND ANTIOXIDANT CAPACITY OF REDSTEM FILAREE (ERODIUM CICUTARIUM)
}

\author{
ERGÜN, F. \\ Kırşehir Ahi Evran University, Faculty of Health Sciences, Kirsehir, Turkey \\ (e-mail:fatma.ergun@ahievran.edu.tr; phone: +90-505-678-4110) \\ (Received 24 $4^{\text {th }}$ Aug 2021; accepted $28^{\text {th }}$ Oct 2021)
}

\begin{abstract}
In this study, the effects of some drying techniques on antioxidant activity of the Erodium cicutarium (L.) L'Her plant, which has ethnobotanical and medical importance, were investigated. The plant samples were divided into three groups; the group dried in sunlight (SD), the group dried in a thermostatic oven at $55^{\circ} \mathrm{C}(\mathrm{OD})$ and the group dried in the shade (DS). Total phenolic substance amounts were determined as $41.27 \pm 2.93 \mathrm{mg} \mathrm{GAE} / \mathrm{g}$ in DS, $15.14 \pm 2.25 \mathrm{mg} \mathrm{GAE} / \mathrm{g}$ in SD and $14.60 \pm 0.86 \mathrm{mg}$ $\mathrm{GAE} / \mathrm{g}$ in OD, respectively. The highest amount of flavonoid substance was determined as $71.99 \pm 2.24 \mathrm{mg} \mathrm{QE} / \mathrm{g}$ in the OD group. The $\mathrm{IC}_{50}$ value, from smallest to largest, was found to be $49.47 \pm 2.69 \mu \mathrm{g} / \mathrm{mL}$ in DS, $71.90 \pm 1.69 \mu \mathrm{g} / \mathrm{mL}$ in SD, and $89.81 \pm 3.42 \mu \mathrm{g} / \mathrm{mL}$ in OD. In addition, it was determined that the highest 1,1-diphenyl-2-picrylhydrazil (DPPH) radical scavenging activity and the highest $\mathrm{Fe}^{3+}-\mathrm{Fe}^{2+}$ reducing capacity were in DS at all concentrations. As a result, it was revealed that the use of shade drying technique would be advantageous in case the E. cicutarium plant was stored by drying, and the total amount of flavonoid substances was affected by the drying time
\end{abstract}

Keyword: erodium cicutarium, antioxidant, dried in sunlight, dried in the shade, dried in a thermostatic oven

\section{Introduction}

Edible plants are one of our main food sources. In addition to basic nutrients such as carbohydrates, fats and vitamins, there are bioactive compounds in plants. The most important type of bioactive compounds in plants are flavonoids and phenolic acids (Demir and Akpınar, 2020). The presence of these compounds affects the antioxidant activity of plants. It has been reported that antioxidants have a preventive effect against cancer, cholesterol problems, diabetes and old age-related diseases (Erlund et al., 2008; Abdolahi, 2018). There are plenty of antioxidants in many plant species, especially cereals, legumes, fruits, and medicinal plants (Foo and Porter, 1981). Some of the species belonging to the Erodium genus are natural plants with these characteristics.

There are 74 species belonging to the genus Erodium, which can be found in many regions, especially in the Mediterranean basin (Fiz et al., 2006). The most common of these species is E. cicutarium. This species is a naturally self-growing five-leaved herbaceous plant with pink blooms in spring (Latimer et al., 2019; Pieroni and Cattero, 2019) (Fig. 1). Although this species is consumed as fresh and dried vegetable in the regions where it grows, it is widely used for traditional medicine (Duke, 2001). E. cicutarium is used as a traditional medicine in many diseases, especially in diseases such as dysentery, uterine bleeding, constipation and diabetes (Molares et al., 2009; Munekata et al., 2019; Tene et al., 2007; Lis-Balchin, 1993; De-la-Cruz et al., 2007; Özgen et al., 2012; Rajaei and Mohamadi, 2012; Asadi-Samani et al., 2016; Safa et al., 2012). The fresh form of the plant is mostly used as a vegetable, and the dry form of the plant is used as a traditional medicine. 


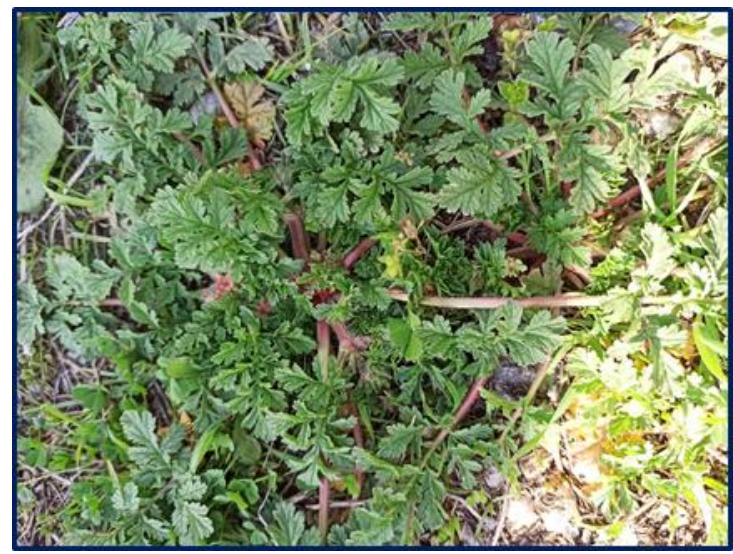

Figure 1. Erodium cicutarium plant

One of the important methods for post-harvest preservation of bioactive compounds and nutritive properties in the plant is drying. Müller (2007) stated in his study that drying is the most appropriate method especially for the preservation of medicinal and aromatic plants. In addition, the drying process provides ease of pharmaceutical use for medicinal and aromatic plants as well as storage (Lorenzi and Matos, 2002). However, the bioactive components and pharmaceutical properties of plants are affected by the drying process (Zhu et al., 2014).

A significant amount of work has been done on the effect of drying methods on the nutritional properties of fruits and vegetables (Deng et al., 2019; Harguindeguy and Fissore, 2020; Martysiak-Żurowska et al., 2020; Thamkaew et al., 2020; Guclu et al., 2021). However, there are very few studies showing how naturally grown herbs are affected by drying methods. In this study, it was aimed to investigate the effects of three different drying techniques on phenolic and flavonoid substance amounts and antioxidant capacity of natural E. cicutarium plant samples collected from Kurşehir region of Turkey.

\section{Materials and methods}

\section{Collecting samples and forming groups}

The study was planned as three groups: sun dried group (DS), shade dried group (SD), and oven dried group (OS). Self-growing E. cicutarium plant specimens (total $3 \mathrm{~kg}$ ) from three different locations $\left(39^{\circ} 06^{\prime} 37^{\circ} \mathrm{N}^{\prime} 34^{\circ} 11^{\prime} 05^{\prime \prime} \mathrm{E} 1047 \mathrm{~m} / 39^{\circ} 08^{\prime} 08^{\circ} \mathrm{N}^{\prime} 34^{\circ} 12^{\prime} 39^{\prime \prime} \mathrm{E} 1151\right.$ $\mathrm{m} / 39^{\circ} 08^{\prime} 58^{\circ} \mathrm{N}^{\prime} 34^{\circ} 06^{\prime} 10^{\prime \prime} \mathrm{E} 1082 \mathrm{~m}$ ) in Kurşehir region of Turkey were manually collected from above-ground parts in May 2021. In the selection of the examples, attention was paid to the fact that the vegetation period and plant sizes were similar. The samples were washed first with tap water and then with distilled water in order to be free from physical impurities. All samples collected after filtration were divided into three groups equally (750 $\mathrm{g}$ for each group) and representatively.

\section{Drying process}

The samples divided into groups were subjected to three different drying methods without waiting. 


\section{Drying in the sun}

The samples were distributed on the glass tray as a whole. It was dried in 2 days (day length $12 \mathrm{~h}$ ) under direct sunlight at temperatures between $16^{\circ} \mathrm{C}$ and $20{ }^{\circ} \mathrm{C}$ in May 2021 (Quispe-Fuentes et al., 2018).

\section{Oven drying}

The samples were distributed as a whole on a glass tray and dried in a thermostatic oven (Elektro-Mag M 420 BP, Turkey) at $55^{\circ} \mathrm{C}$ for $12 \mathrm{~h}$ (Jafari et al., 2016; Kamel et al., 2013).

\section{Drying in the shade}

The samples were distributed as a whole on a glass tray and drying was carried out in the shade with natural airflow and ambient temperature $\left(21 \pm 5^{\circ} \mathrm{C}\right)$ (Pirbalouti et al., 2017).

The drying period in this study were determined as the moment when the samples reached constant weight. After drying, the samples were stored in polyethylene containers at $+4{ }^{\circ} \mathrm{C}$ in the dark.

\section{Preparation of extracts}

Merck and Sigma brand chemicals were used in the study. Plant extracts were prepared using methanol. For this, $10 \mathrm{~g}$ of plant samples from each group were weighed separately, ground in a grinder and placed in three 1-liter closed flasks separately. Then, twenty times of methanol $(200 \mathrm{~mL})$ was added to the samples and mixed in a magnetic stirrer. The resulting methanol extracts were filtered. This process was repeated three times at regular intervals for each group separately. The obtained extracts were removed at $45^{\circ} \mathrm{C}$ with the help of methanol evaporator and the extracts were stored at $+4^{\circ} \mathrm{C}$ for study (Ergün, 2021a).

\section{Preparation of stock solutions}

Stock solutions were prepared from SD, OS and DS extracts using methanol at a concentration of $1000 \mathrm{ppm}$ and stored at $+4{ }^{\circ} \mathrm{C}$ for the study.

\section{Determination of total phenolic substance}

Total phenolic substance determination of the groups was made according to the Folin-Ciocaltaeu method (Slinkard and Singleton, 1977). A standard graph was prepared using gallic acid. $50 \mu \mathrm{L}$ of the prepared stock solutions were taken, and their volume was completed to $1840 \mu \mathrm{L}$ with distilled water. $40 \mu \mathrm{L}$ of Folin-Ciocalteu reagent (FCR) was added to the mixtures separately. After waiting for $3 \mathrm{~min}$ at room temperature, $120 \mu \mathrm{L}$ of $2 \%(\mathrm{w} / \mathrm{v}) \mathrm{Na}_{2} \mathrm{CO}_{3}$ solution was added to them. The resulting mixtures were incubated for $2 \mathrm{~h}$ at room temperature. The absorbances of the samples were read at $760 \mathrm{~nm}$ against a blank with distilled water instead of the sample (Optima SP-3000, Tokyo/Japan). Three parallel studies were performed for the measurements. The total phenolic contents of the extracts were determined as equivalent to gallic acid (mg GAE/g) using the equation obtained from the standard gallic acid graph.

\section{Determination of total flavonoid substance}

The flavonoid contents of the groups were determined as equivalent to quercetin using the aluminum nitrate method (Nieva Moreno et al., 2000). Quercetin was used to 
prepare standard graphics. $50 \mu \mathrm{L}$ of the stock solutions were taken and the volume was made up to $1920 \mu \mathrm{L}$ with methanol. $40 \mu \mathrm{L}$ of $1 \mathrm{M}$ potassium acetate was added and after 1 min $40 \mu \mathrm{L}$ of $10 \%$ aluminum nitrate was added. Absorbance was read at $415 \mathrm{~nm}$ (Optima SP-3000, Tokyo/Japan) after an incubation period of $40 \mathrm{~min}$. Three parallel studies were performed for the measurements. The total flavonoid contents of the extracts were determined as equivalent to quercetin using the equation obtained from the standard quercetin graph (mg QE/g).

\section{Determination of DPPH・ free radical scavenging activity}

The free radical scavenging activities of the groups were determined using the Blois (1958) method. 1,1-diphenyl-2-picrylhydrazil (DPPH•) $(0.1 \mathrm{mM})$ solution was used as the free radical and 2,6-di-t-butyl-1-hydroxytoluene (BHT) (1000 ppm) as a standard. $20,40,60,80$ and $100 \mu \mathrm{L}$ of SD, OS, DS and BHT stock solutions were taken and their volumes were made up to $400 \mu \mathrm{L}$ with methanol. Then, $1600 \mu \mathrm{L}$ of $\mathrm{DPPH} \bullet$ solution was added. Control was prepared using methanol under the same conditions. After incubation of the prepared solutions for $30 \mathrm{~min}$ in the dark at room temperature, the absorbance changes at $517 \mathrm{~nm}$ were measured against methanol (Optima SP-3000, Tokyo/Japan). Decreased absorbances gave the remaining amount of free DPPH• solution, i.e., free radical scavenging activity (Jaradat et al., 2017).

The \% DPPH• radical scavenging activity was calculated with the formula given below:

$$
\% \mathrm{DPPH} \bullet \text { radical scavenging activity }=\left[\left(\mathrm{A}_{0}-\mathrm{A}_{1}\right) / \mathrm{A}_{0}\right] \times 100
$$

where $\mathrm{A}_{0}$ : absorbance of control reaction, $\mathrm{A}_{1}$ : absorbance of plant extracts and standard solutions.

\section{Determination of ferric reducing power}

The determination of the $\mathrm{Fe}^{3+}$ reducing power of the groups was made according to Oyaizu (1986). BHT was used as a standard. BHT and stock solutions were placed in a tube with a concentration of $10,20,30,40$ and $50 \mu \mathrm{g} / \mathrm{mL}$. Pure water was added to make a total volume of $1.0 \mathrm{~mL}$. On top of these solutions, $2.5 \mathrm{~mL}$ of phosphate buffer $(0.2 \mathrm{M} \mathrm{pH}$ 6.6) and potassium ferricyanide (1\%) solution were added and kept in a water bath at $50{ }^{\circ} \mathrm{C}$ for $20 \mathrm{~min}$. Then $2.5 \mathrm{~mL}$ of $10 \%$ trichloroacetic acid (TCA) was added and vortexed. $2.5 \mathrm{~mL}$ ultrapure water and $0.5 \mathrm{~mL}$ iron (III) chloride $(0.1 \%)$ were added to $2.5 \mathrm{~mL}$ samples from vortexed tubes and the absorbance was read at $700 \mathrm{~nm}$ against the blank (Optima SP-3000, Tokyo/Japan). Results were calculated as ascorbic acid equivalent using the equation obtained from the standard graph ( $\mu \mathrm{g} \mathrm{AAE} / \mathrm{mL}$ ) (Ergün, 2021b)

\section{Statistical analysis}

The data obtained in the study were analyzed using SPSS 15.0 and Windows statistical software programs, and the effect of drying methods was investigated. In the study, which was planned as three groups and three replicates, one-way analysis of variance and DUNCAN test were used to compare groups. All results were given as mean \pm standard deviation. Significance test was performed according to $\mathrm{P}<0.05$ and the results were evaluated accordingly. 


\section{Results and discussion}

Natural plants, which date back to centuries and are named differently by the peoples of the region, are very important for sustainable life. Among them, there are plants that have medicinal properties as well as nutritional properties. In addition, the increasing interest in natural nutrition and alternative medicine has increased the importance of such plants. E. cicutarium, a member of the Geraniaceae family, is a herbaceous plant with medicinal plant properties as well as nutritional properties. It grows naturally. Its leaves are consumed fresh and dried, raw or cooked. In this study, total phenolic and flavonoid substance content, DPPH• radical scavenging activities and $\mathrm{Fe}^{+3}$ reducing power capacity were determined in the samples belonging to SD, OD, DS groups.

The Folin-Ciocaltaeu method was used to determine the amount of phenolic substances. Gallic acid was calculated as equivalent to gallic acid using the standard graph $(y=0.0745 x-0.0011)$. In terms of phenolic substance amounts, it was found that SD and OD groups were similar among themselves, and the difference between them and the DS group was significant $(\mathrm{P}<0.05)$.

The amounts of phenolic substances were determined as $41.27 \pm 2.93 \mathrm{mg}$ GAE/g in $\mathrm{DS}, 15.14 \pm 2.25 \mathrm{mg} \mathrm{GAE} / \mathrm{g}$ in $\mathrm{SD}$, and $14.60 \pm 0.86 \mathrm{mg} \mathrm{GAE} / \mathrm{g}$ in $\mathrm{OD}$, respectively (Table 1). In studies conducted on Erodium species, phenolic substance amounts were reported as $25.40 \pm 2.07 \mathrm{mg} \mathrm{GAE} / \mathrm{g}$ in Erodium bryoniifolium (El-Hela et al., 2013), $10.8 \mathrm{mg} \mathrm{GAE} / \mathrm{g}$ in Erodium bryoniifolium Boiss (Alali et al., 2007), $248.08 \pm 2 \mathrm{mg}$ GAE $/ \mathrm{mL}$ in Erodium glaucophyllum, $180 \pm 4.02 \mathrm{mg} \mathrm{GAE} / \mathrm{mL}$ in Erodium hirtum, and $124 \pm 6 \mathrm{mg}$ GAE$/ \mathrm{mL}$ in Erodium guttatum (Hamza et al., 2018).

While the values we found are similar to E. bryoniifolium and E. bryoniifolium Boiss, they are lower than the values found in other species. This result we found proves that the phytochemical structures of plants differ between species. It was concluded that the difference between the groups was due to the drying technique applied. Because phytochemical properties are affected depending on the heat applied during drying. (Thamkaew et al., 2020). In addition, the applied heat may be perceived by the plant as a stress factor and cause the production of phenolic compounds by the plant in response (Cooper and Rao, 1992).

Table 1. The amount of phenolic substances belonging to the groups $(P<0.05)$

\begin{tabular}{c|c}
\hline Groups & The amount of total phenolic $(\mathbf{m g}$ GAE/g) \\
\hline SD & $15.14 \pm 2.25^{\mathrm{b}}$ \\
OD & $14.60 \pm 0.86^{\mathrm{b}}$ \\
DS & $41.27 \pm 2.93^{\mathrm{a}}$ \\
\hline
\end{tabular}

The total amount of flavonoid substance was calculated as equivalent to quercetin using the standard graph of quercetin $(y=0.0574 \mathrm{x}+0.0387)$. The differences between the groups in terms of total flavonoid content were found to be significant at the $\mathrm{P}<0.05$ level and it was detected that the highest value was $71.99 \pm 2.44 \mathrm{mg} \mathrm{QE} / \mathrm{g}$ in OD and the lowest value was $19.61 \pm 1.25 \mathrm{mg}$ QE/g in SD (Table 2).

In similar studies conducted in different species, the total amount of flavonoids was reported as $34 \pm 1 \mathrm{mg}$ QE/g in Erodium glaucophyllum (Bakari et al., 2018), $91.97 \pm 1.56 \mathrm{mg} \mathrm{RE} / \mathrm{g}$ in Erodium glaucophyllum, $63 \pm 4.1 \mathrm{mg} \mathrm{RE} / \mathrm{g}$ in Erodium hirtum, and $52 \pm 2.3 \mathrm{mg} \mathrm{RE} / \mathrm{g}$ in Erodium guttatum (Hamza et al., 2018). 
This result we found proves that the phytochemicals in plants are affected differently by the drying process (Hossain et al., 2010). In addition, failure to adjust the heat to be applied well may cause deterioration of phytochemicals (Orphanides et al., 2013).

Table 2. The amount of flavonoid substance belonging to the groups $(P<0.05)$

\begin{tabular}{c|c}
\hline Groups & The amount of total flavonoid $(\mathbf{m g} \mathbf{Q E} / \mathbf{g})$ \\
\hline SD & $19.61 \pm 1.25^{\mathrm{c}}$ \\
OD & $71.99 \pm 2.24^{\mathrm{a}}$ \\
DS & $27.16 \pm 1.91^{\mathrm{b}}$ \\
\hline
\end{tabular}

$\mathrm{DPPH} \cdot$ free radical and BHT as a standard were used to determine the free radical scavenging activity of the groups. DPPH $\bullet$ radical scavenging activities of the extracts and BHT were calculated (\%) (Table 3). Parallel to the increase in concentration (20$100 \mu \mathrm{g} / \mathrm{mL}$ ), it was observed an increase in DPPH • radical scavenging activities in both groups and BHT. The differences between the groups were significant at the $\mathrm{P}<0.05$ level. The highest activity value was detected in DS at all concentrations. In addition, the activity values in DS were higher than the value of BHT used as a standard. In a similar study on E. glaucophyllum, the activities detected in ethyl acetate and chloroform extracts were higher than the values we found (Radhia et al., 2018).

Table 3. \% DPPH radical scavenging activities of groups and BHT $(P<0.05)$

\begin{tabular}{c|c|c|c|c|c}
\hline Extracts/standard & $\mathbf{2 0} \boldsymbol{\mu g} / \mathbf{m L}$ & $\mathbf{4 0} \boldsymbol{\mu g} / \mathbf{m L}$ & $\mathbf{6 0} \mathbf{\mu g} / \mathbf{m L}$ & $\mathbf{8 0} \boldsymbol{\mu g} / \mathbf{m L}$ & $\mathbf{1 0 0} \boldsymbol{\mu g} / \mathbf{m L}$ \\
\hline SD & $7.54 \pm 2.05^{\mathrm{c}}$ & $25.07 \pm 2.12^{\mathrm{c}}$ & $42.10 \pm 0.82^{\mathrm{c}}$ & $57.09 \pm 2.14^{\mathrm{c}}$ & $70.96 \pm 2.68^{\mathrm{c}}$ \\
OD & $0.47 \pm 0.14^{\mathrm{d}}$ & $17.54 \pm 0.81^{\mathrm{d}}$ & $27.99 \pm 7.19^{\mathrm{d}}$ & $44.14 \pm 2.39^{\mathrm{d}}$ & $56.56 \pm 0.25^{\mathrm{d}}$ \\
DS & $19.31 \pm 1.85^{\mathrm{a}}$ & $46.91 \pm 1.62^{\mathrm{a}}$ & $63.03 \pm 1.10^{\mathrm{a}}$ & $79.13 \pm 6.26^{\mathrm{a}}$ & $83.58 \pm 0.15^{\mathrm{a}}$ \\
BHT & $13.20 \pm 3.25^{\mathrm{b}}$ & $42.01 \pm 1.42^{\mathrm{b}}$ & $55.50 \pm 2.34^{\mathrm{b}}$ & $65.81 \pm 3.51^{\mathrm{b}}$ & $79.95 \pm 2.34^{\mathrm{b}}$ \\
\hline
\end{tabular}

The concentration of the extract and standard substance that inhibited $50 \%$ of DPPH • radical removal was determined as $\mathrm{IC}_{50}$. This value was calculated using the graphs obtained by placing the \% DPPH• radical scavenging activity values against the studied concentrations (Table 4). There is an inverse correlation between the $\mathrm{IC}_{50}$ value and the $\mathrm{DPPH} \bullet$ radical scavenging activity. A low $\mathrm{IC}_{50}$ value means a high radical scavenging activity.

Table 4. $I C_{50}$ values of groups and $B H T(P<0.05)$

\begin{tabular}{c|c}
\hline Extracts and standard & $\mathbf{I C}_{\mathbf{5 0}}(\boldsymbol{\mu g} / \mathbf{m L})$ \\
\hline SD & $71.90 \pm 1.69^{\mathrm{b}}$ \\
OD & $89.81 \pm 3.42^{\mathrm{a}}$ \\
DS & $49.47 \pm 2.69^{\mathrm{d}}$ \\
BHT & $58.34 \pm 0.86^{\mathrm{c}}$ \\
\hline
\end{tabular}

The difference between the groups in terms of $\mathrm{IC}_{50}$ value was found to be significant $(\mathrm{P}<0.05)$. The $\mathrm{IC}_{50}$ value order of the groups was detected as $71.90 \pm 1.69$ 
$\mu \mathrm{g} / \mathrm{mL}$ in $\mathrm{SD}, 89.81 \pm 3.42 \mu \mathrm{g} / \mathrm{mL}$ in OD and $49.47 \pm 2.69 \mu \mathrm{g} / \mathrm{mL}$ in DS. In similar studies, the $\mathrm{IC}_{50}$ value was $38.8 \pm 0.2 \mu \mathrm{g} / \mathrm{mL}$ in E. glaucophyllum flowers and $79.2 \pm 0.6 \mu \mathrm{g} / \mathrm{mL}$ in its leaves, $20.29 \pm 2.64 \mu \mathrm{g} / \mathrm{mL}$ in E. glaucophyllum, $49.1 \pm 3.6$ $\mu \mathrm{g} / \mathrm{mL}$ in E. hirtum and $56.9 \pm 3.3 \mu \mathrm{g} / \mathrm{mL}$ in E. guttatum (Hamza et al., 2018; Bakari et al., 2018). In addition, in a similar study conducted on Kappaphycus alvarezii, it was reported that the highest $\mathrm{IC}_{50}$ value was in the Oven-dried $40{ }^{\circ} \mathrm{C}$ group, and the lowest value was in the Sun-dried group (Ling et al., 2015). The $\mathrm{Fe}^{3+}-\mathrm{Fe}^{2+}$ reducing capacity of SD, OD and DS extracts and BHT was determined by using the method of Oyaizu (1986). In the measurements of $\mathrm{Fe}^{3+}$ reducing capacity, absorbances at $700 \mathrm{~nm}$ were determined and a graph was obtained by placing the absorbance values against the concentration (Fig. 2). In this graph, increasing absorbance values show the reducing power capacity.

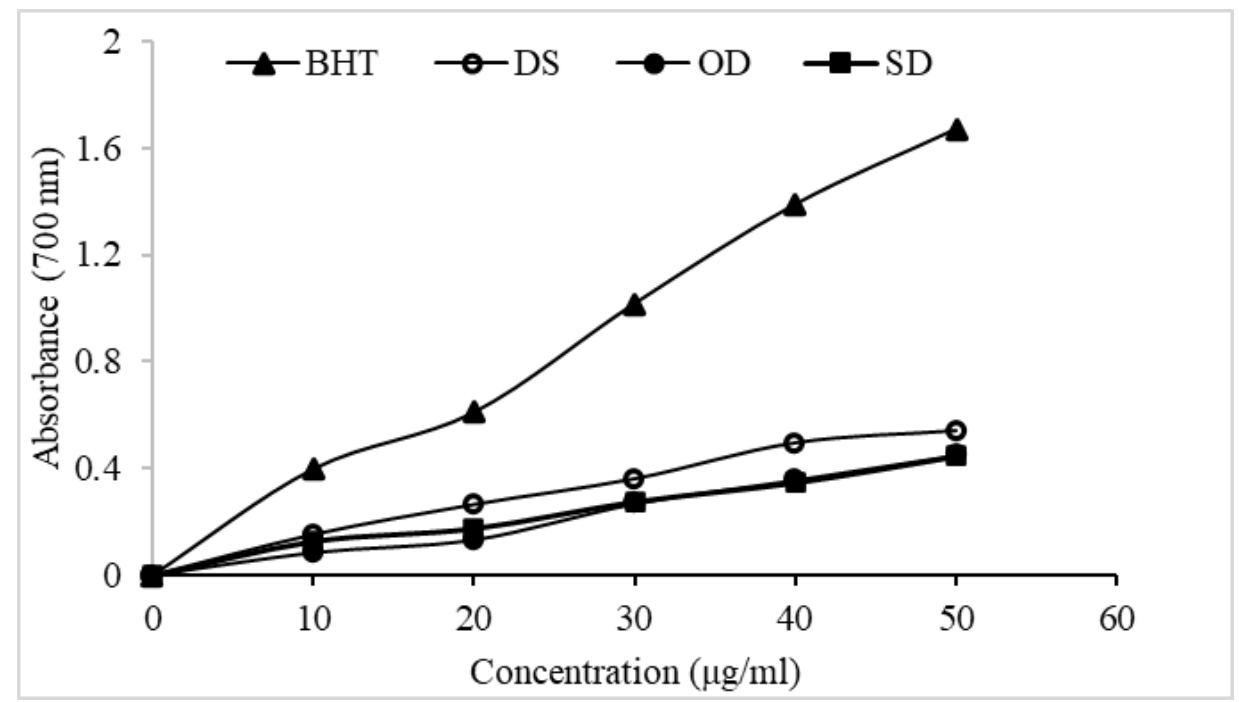

Figure 2. Comparison of the $\mathrm{Fe}^{3+}-\mathrm{Fe}^{2+}$ reducing capacity of the extracts of the groups with BHT $(20-50 \mu \mathrm{g} / \mathrm{mL})$

In addition, the $\mathrm{Fe}^{3+}-\mathrm{Fe}^{2+}$ reducing power of the groups was calculated as ascorbic acid equivalent ( $\mu \mathrm{g}$ AAE/mL) using the ascorbic acid standard graph (Table 5). The differences between the groups were found to be significant $(\mathrm{P}<0.05)$. Similarity was found between SD and OD and DS. Respectively, it detected as $1231.01 \pm 4.83 \mu \mathrm{g}$ $\mathrm{AAE} / \mathrm{mL}$ in BHT, $129.43 \pm 6.80 \mu \mathrm{g}$ AAE $/ \mathrm{mL}$ in $\mathrm{DS}, 116.59 \pm 4.90 \mu \mathrm{g}$ AAE $/ \mathrm{mL}$ in SD and $83.29 \pm 4.12 \mu \mathrm{g}$ AAE $/ \mathrm{mL}$ in OD. In the study conducted by Jaradat et al., in 2017 on the same species, the values they found to be equivalent to trolox and the values we found were similar (Jaradat et al., 2017).

Table 5. $\mathrm{Fe}^{3+}-\mathrm{Fe}^{2+}$ reducing capacity of groups and BHT $(P<0.05)$

\begin{tabular}{c|c}
\hline Extracts and standard & $\boldsymbol{\mu g} \mathbf{A A E} / \mathbf{m L}$ \\
\hline SD & $116.59 \pm 4.90^{\mathrm{bc}}$ \\
OD & $83.29 \pm 4.12^{\mathrm{c}}$ \\
DS & $129.43 \pm 6.80^{\mathrm{b}}$ \\
BHT & $1231.01 \pm 4.83^{\mathrm{a}}$ \\
\hline
\end{tabular}




\section{Conclusion}

Recently, an increase has been observed in studies on the effects of drying techniques on phytochemicals. For this purpose, studies have been carried out on many foodstuffs (Osae et al., 2019; Al-juhaimi et al., 2018; Arvaniti et al., 2019; Mustafa, et al., 2019; Zahoor et al., 2019). Plants perceive the drying process as a stress factor. This affects the amount of antioxidants in plants, depending on the application (Guclu et al., 2021). Green plants are more affected by this condition than woody plants (Yousif et al., 1999). In this study, it was observed that the phytochemical structure of the $E$. cicutarium plant was affected by drying in sunlight, drying in a thermostatic oven at $55^{\circ} \mathrm{C}$ and drying in the shade. It was determined that the shade drying method was advantageous in terms of total phenolic substance content, \% DPPH radical removal activities, $\mathrm{IC}_{50}$ value and $\mathrm{Fe}^{3+}-\mathrm{Fe}^{2+}$ reducing capacity, and the method of drying in a thermostatic oven at $55{ }^{\circ} \mathrm{C}$ was advantageous in terms of total flavonoid substance content. Results in this study were similar to those found results by Fernandes et al., 2011 and Jang et al., 2020. As a result, it was concluded that there is a need for new studies on the determination of the compounds responsible for the antioxidant activity of the E. cicutarium plant, which is valuable in terms of phytochemicals, its usability as a natural antioxidant and the kinetics of the drying process. In addition, it is recommended to develop new drying techniques that will least affect the existing properties of plant resources.

Funding. This research did not receive any specific grant from funding agencies in the public, commercial, or not-for-profit sectors.

\section{REFERENCES}

[1] Abdolahi, N., Soltani, A., Mirzaali, A., Soltani, S., Balakheyli, H., Aghaei, M. (2018): Antibacterial and antioxidant activities and phytochemical properties of Punica granatum flowers in Iran. - Iranian Journal of Science and Technology, Transactions A: Science 42: 1105-1110.

[2] Alali, F. Q., Tawaha, K., El-Elimat, T., Syouf, M., El-Fayad, M., Abulaila, K., Nielsen, S. J., Wheaton, W. D., Falkinham, J. O., Oberlies, N. H. (2007): Antioxidant activity and total phenolic content of aqueous and methanolic extracts of Jordanian plants: an ICBG project. - Natural Product Research 21: 1121-1131.

[3] Al-juhaimi, F., Ghafoor, K., Özcan, M. M., Jahurul, M. H. A., Babiker, E. E., Jinap, S., Zaidul, I. S. M. (2018): Effect of various food processing and handling methods on preservation of natural antioxidants in fruits and vegetables. - Journal of Food Science and Technology 55(10): 3872-3880.

[4] Arvaniti, O. S., Samaras, Y., Gatidou, G., Thomaidis, N. S., Stasinakis, A. S. (2019): Review on fresh and dried figs: chemical analysis and occurrence of phytochemical compounds, antioxidant capacity and health effects. - Food Research International 119: 244-267.

[5] Asadi-Samani, M., Moradi, M. T., Bahmani, M., Shahrani, M. (2016): Antiviral medicinal plants of Iran: a review of ethnobotanical evidence. - International Journal of PharmTech Research 9: 427-434.

[6] Bakari, S., Hajlaoui, H., Daoud, A., Mighri, H., Ross-Garcia, J. M., Gharsallah, N., Kadri, A. (2018): Phytochemicals, antioxidant and antimicrobial potentials and LC-MS analysis of hydroalcoholic extracts of leaves and flowers of Erodium glaucophyllum collected from Tunisian Sahara. - Food Science and Technology 38: 310-317. 
[7] Blois, M. S. (1958): Antioxidant determinations by the use of a stable free radical. Nature 181: 1199-1200.

[8] Cooper, J. E., Rao, R. (1992): Localised changes in flavonoid biosynthesis in roots of Lotus pendiculatus after infection by Rhizobium loti. - Plant Physiology 100: 444-450.

[9] De-la-Cruz, H., Vilcapoma, G., Zevallos, P. A. (2007): Ethnobotanical study of medicinal plants used by the Andean people of Canta, Lima, Peru. - Journal of Ethnopharmacology 111: 284-294.

[10] Demir, T., Akpınar, Ö. (2020): Biological activities of phytochemicals in plants. Turkish Journal of Agriculture-Food Science and Technology 8(8): 1734-1746.

[11] Deng, L. Z., Mujumdar, A. S., Zhang, Q., Yang, X. H., Wang, J., Zheng, Z. A., Gao, Z. J., Xiao, H. W. (2019): Chemical and physical pretreatments of fruits and vegetables: effects on drying characteristics and quality attributes. A comprehensive review. Critical Reviews in Food Science and Nutrition. 59(9): 1408-32.

[12] Duke, J. A. (2001): (Ed.) Handbook of Edible Weeds. - CRC Press, Boca Ratón, FL.

[13] El-Hela, A. A., Abdel-Hady, N. M., Dawoud, G. T., Hamed, A. M., Morsy, T. A. (2013): Phenolic content, antioxidant potential and Aedes aegyptii ecological friend larvicidal activity of some selected Egyptian plants. - Journal of the Egyptian Society of Parasitology 43: 215-234.

[14] Ergün, F. (2021a): Lonicera iberica M. Bieb.: investigation antioxidant activity and bioactive chemicals. - Turkish Journal of Agriculture - Food Science and Technology 9(6): 1124-1128.

[15] Ergün, F. (2021b): Cotoneaster Transcaucasicus Pojark. Determination of bioactive component amounts and antioxidant activities in fruit extracts. - Turkish Journal of Agriculture - Food Science and Technology 9(7): 1258-1263.

[16] Erlund, I., Koli, R., Alfthan, G., Marniemi, J., Puukka, P., Mustonen, P., Mattila, P., Jula, A. (2008): Favorable effects of berry consumption on platelet function, blood pressure, and HDL cholesterol. - Am. J. of Clin. Nutrition 87(2): 323-331.

[17] Fernandes, L., Casal, S., Pereira, J. A., Saraıva, J. A., Ramalhosa, E. (2018): Effects of different drying methods on the bioactive compounds and antioxidant properties of edible Centaurea (Centaurea cyanus) petals. - Brazilian Journal of Food Technology 21(0): 110.

[18] Fiz, O., Vargas, P., Alarcon, M. L., Aldasoro, J. J. (2006): Phylogenetic relationships and evolution in Erodium (Geraniaceae) based on trnL-trnF sequences. - Systematic Botany 31(4): 739-763.

[19] Foo, L. Y., Porter, L. J. (1981): The structure of tannins of some edible fruits. - Journal Science Food Agricaltural 32: 711-716.

[20] Guclu, G., Keser, D., Kelebek, H., Keskin, M., Şekerli, Y. E., Soysal, Y., Selli, S. 2021: Impact of production and drying methods on the volatile and phenolic characteristics of fresh and powdered sweet red peppers. - Food Chemistry 338: 128129.

[21] Hamza, G., Emna, B. H., Yeddes, W., Dhouafli, Z., Moufida, T. S., El Akrem, H. (2018): Chemical composition, antimicrobial and antioxidant activities data of three plants from Tunisia region: Erodium glaucophyllum, Erodium hirtum and Erodium guttatum. - Data Brief 19: 2352-2355.

[22] Harguindeguy, M., Fissore, D. (2020): On the effects of freeze-drying processes on the nutritional properties of foodstuff: a review. - Drying Technology 38: 846-868.

[23] Hossain, M. B., Barry-Ryan, C., Martin-Diana, A. B., Brunton, N. P. (2010): Effect of drying method on the antioxidant capacity of six Lamiaceae herbs. - Food Chemistry 123(1): 85-91.

[24] Jafari, S. M., Azizi, D., Mirzaei, H., Dehnad, D. (2016): Comparing quality characteristics of oven-dried and refractance window-dried kiwifruits. - Journal of Food Processing and Preservation 40: 362-372. 
[25] Jang, M., Kim, K. H., Kim, G. H. (2020): Antioxidant capacity of thistle (Cirsium japonicum) in various drying methods and their protection effect on neuronal PC12 cells and Caenorhabditis elegans. - Antioxidants 9(3): 200.

[26] Jaradat, N., Al-Masri, M., Zaid, A. N., Othman, D. G. (2018): Pharmacological and phytochemical screening of Palestinian traditional medicinal plants Erodium laciniatum and Lactuca orientalis. - Journal of Complementary and Integrative Medicine 15(1): 116.

[27] Kamel, S. M., Thabet, H. A., Algadi, E. A. (2013): Influence of drying process on the functional properties of some plants. - Chemistry and Materials Research 3: 1-8.

[28] Latimer, A. M., Jacobs, B. S., Gianoli, E., Heger, T., Salgado-Luarte, C. (2019): Parallel functional differentiation of an invasive annual plant on two continents. - AoB Plants 11: $1-16$.

[29] Ling, A. L. M., Yasir, S., Matanjun, P., Abu Bakar, M. F. (2015): Effect of different drying techniques on the phytochemical content and antioxidant activity of Kappaphycus alvarezii. - Journal of Applied Phycology. 27: 1717-1723.

[30] Lis-Balchin, M. (1993): The essential oils of Pelargonium grossularioides and Erodium cicutarium (Geraniaceae). - Journal of Essential Oil Research 5: 317-318.

[31] Lorenzi, H., Matos, F. J. A. (2002): Plantasmedicinais no Brasil: Nativasexóticas. Instituto Plantarum, Nova Odessa.

[32] Martysiak-Żurowska, D., Rożek, P., Puta, M. (2020): The effect of freeze-drying and storage on lysozyme activity, lactoferrin content, superoxide dismutase activity, total antioxidant capacity and fatty acid profile of freeze-dried human milk. - Drying Technology 1-11.

[33] Molares, S., Ladio, A. (2009): Ethnobotanical review of the Mapuche medicinal flora: use patterns on a regional scale. - Journal of Ethnopharmacology 122(2): 251-260.

[34] Munekata, P. E. S., Alcántara, C., Collado, M. C., Garcia-Perez, J. V., Saraiva, J. A., Lopes, R. P., Barba, F. J., do Prado Silva, L., Sant'Ana, A. S., Fierro, E. M., Lorenzo, J. M. (2019): Ethnopharmacology, phytochemistry and biological activity of Erodium species: a review. - Food Research International 126: 108659.

[35] Mustafa, I., Chin, N. L., Fakurazi, S., Palanisamy, A. (2019): Comparison of phytochemicals, antioxidant and anti-inflammatory properties of sun-, oven- and freezedried ginger extracts. - Foods 8: 456.

[36] Müller, J. (2007): Convective drying of medicinal, aromatic and spice plants: a review. Stewart Postharvest Review 3(4): 1-6.

[37] Nieva Moreno, M. I., Isla, M. I., Sampieto, A. R., Vattuone, M. A. (2000): Comparison of the free radical-scavenging activity of propolis from several regions of Argentina. Journal of Ethnopharmacology 71: 109-114.

[38] Orphanides, A., Goulas, V., Gekas, V. (2013): Effect of drying method on the phenolic content and antioxidant capacity of spearmint. - Czech Journal of Food Sciences 31: 509513.

[39] Osae, R., Zhou, C., Xu, B., Tchabo, W., Tahir, H. E., Mustapha, A. T., Ma, H. (2019): Effects of ultrasound, osmotic dehydration, and osmosonication pretreatments on bioactive compounds, chemical characterization, enzyme inactivation, color, and antioxidant activity of dried ginger slices. - Journal of Food Biochemistry 43(5): e12832.

[40] Oyaizu, M. (1986): Studies on products of browning reactions: antioxidative activities of products of browning reaction prepared from glucosamine. - Japanese Journal of Nutrition 44: 307-315.

[41] Özgen, U., Kaya, Y., Houghton, P. (2012): Folk medicines in the villages of Ilıca District (Erzurum, Turkey). - Turkish Journal of Biology 36: 93-106.

[42] Pieroni, A., Cattero, V. (2019): Wild vegetables do not lie: comparative gastronomic ethnobotany and ethnolinguistics on the Greek traces of the Mediterranean diet of southeastern Italy. - Acta Botanica Brasilica 33: 198-211. 
[43] Pirbalouti, A. G., Salehi, S., Craker, L. (2017): Effect of drying methods on qualitative and quantitative properties of essential oil from the aerial parts of coriander. - Journal of Applied Research on Medicinal and Aromatic Plants 4(1): 35-40.

[44] Quispe-Fuentes, I., Vega-Gálvez, A., Aranda, M. (2018): Evaluation of phenolic profiles and antioxidant capacity of maqui (Aristotelia chilensis) berries and their relationships to drying methods. - Journal of the Science of Food and Agriculture 98(11): 4168-4176.

[45] Radhia, A., Hanen, N., Abdelkarim, B. A., Mohamed, N. (2018): Phytochemical screening, antioxidant and antimicrobial activity of Erodium glaucophyllum (L.) L'Hérit. - Journal of Biomedical Sciences 7: 13.

[46] Rajaei, P., Mohamadi, N. (2012): Ethnobotanical study of medicinal plants of Hezar mountain allocated in south east of Iran. - Iranian Journal of Pharmaceutical Research 11: 1153-1167.

[47] Safa, O., Soltanipoor, M. A., Rastegar, S., Kazemi, M., Dehkordi, K. N., Ghannadi, A. R. (2012): An ethnobotanical survey on Hormozgan province, Iran. - Avicenna Journal of Phytomedicine 3: 64-81.

[48] Slinkard, K., Singleton, V. L. (1977): Total phenol analyses: automation and comparison with manual methods. - American Journal of Enology and Viticulture 28: 49-55.

[49] Tene, V., Malagón, O., Finzi, P. V., Vidari, G., Armijos, C., Zaragoza, T. (2007): An ethnobotanical survey of medicinal plants used in Loja and Zamora-Chinchipe, Ecuador. - Journal of Ethnopharmacology 111(1): 63-81.

[50] Thamkaew, G., Sjöholm, I., Galindo, F. G. (2020): A review of drying methods for improving the quality of dried herbs. - Critical Reviews in Food Science and Nutrition 18: $1-24$.

[51] Yousif, A. L., Scaman, C. H., Durance, T. D., Girard, B. (1999): Flavor volatiles and physical properties of vacuum-microwave and airdried sweet basil (Ocimum basilicum L.). - Journal of Agricultural and Food Chemistry 47: 4777-4781.

[52] Zahoor, I., Khan, M. A. (2019): Microwave assisted convective drying of bitter gourd: drying kinetics and effect on ascorbic acid, total phenolics and antioxidant activity. Journal of Food Measurement and Characterization 3(3): 2481-90.

[53] Zhu, Y., Pu, B., Xie, G. (2014): Dynamic changes of flavonoids contents in the different parts of rhizome of Belamcanda chinensis during the thermal drying process. - Molecules 19(7): 10440-10454. 